\title{
The Impact of Staff Turnover on Performance: A Case of the North West Provincial Department of South Africa

\author{
Molefakgotla Alex Molefi
}

North West University, RSA Private Bag X2046, Mmabatho, 2735

Email: Molefakgotla.Molefi@nwu.ac.za

Ntebogang Dinah Moroke (Ph.D)

North West University, RSA

Email: Ntebo.Moroke@nwu.ac.za

Katlego Tlholoe

Email: katlego.tholoe@gmail.com

\section{Doi:10.5901/mjss.2014.v5n23p117}

\section{Abstract}

There is a general consensus regarding the effects of high staff turnover on the smooth running of various institutions. The purpose of this study is to establish the effect of staff turnover on performance of employees in the North West Provincial Department of South Africa. Questionnaires and document analysis were blended to capture authenticity and exhaustiveness of the data. Participants included the 70 employees in the said department who all filled and returned the questionnaire. Both inferential and descriptive statistics were used to present the results. A chi-square analysis was used as a method for data analysis in this study. Descriptive statistics were also used to describe the profiles of employees. The findings showed that the majority of employees are dissatisfied due many reasons and this causes lots of voluntary resignations among employees. Low productivity in the department is as a result of employee dissatisfaction borne as a result of management's ignorance. The study recommends that the department should improve on mechanisms of getting feedback from its staff members regarding problems that have been identified as causes of high staff turnover rates. In addition, staff taking over duties performed by those who exited must be given proper orientation and recognition for going an extra mile. It was further recommended to the management of this organisation to give an exceptional attention to controllable factors such as, performance appraisals, salaries, interrelations between staff, orientation of newly appointed employees, etc. A relevant continual training was also recommended to prepare employees for promotions and development.

Keywords: Staff turnover, employee performance, labour costs, resignation

\section{Introduction}

Staff turnover refers to the proportion of employees who leave the department over a set period (often on a year-to-year basis), expressed as a percentage of total workforce numbers. At its broadest, according to Grobler et al. (2006) and Nel et al. (2008), the term is used to encompass all leavers, both voluntary and involuntary including those who resign, retire or are made redundant. This scenario may be described as overall or crude employee turnover (Lee, 2011). It is also possible to calculate more specific breakdowns of turnover data such as redundancy-related turnover or resignation levels. The latter is particularly useful for employers in assessing the effectiveness of people management in their departments. Van der Merwe and Miller (1988) view controllable staff turnover as resignations and dismissals, and define resignation as the ending of an employment contract by the employee.

The South African provincial government departments have been wrestling with the problem of retaining available talent. According to Harris (2007), talented job candidates in the global skills market have the luxury of choice. This poses an unremitting unhealthy competition among government departments in the entire country. Some departments tend to gain at the expense of others loosing employees to them. The departments are currently going to great lengths to retaining their employees. Competition has therefore put skilled employees who are already in short supply under pressure as they are being attracted by more than one department at a time with various kinds of incentives. According to Doke (2008), many newly qualified South African graduates are drawn to foreign shores with the promise of better 
remuneration, wider scope and more opportunities, leaving departments hard pressed to fill their vacancies with the right candidates.

Upon our realisation, turnover in the provincial department of Public Works (DoPW) is of major concern to management and this impact tremendously on normal day-to-day operations of this department. Countless numbers of people are seen leaving employment voluntarily mainly due the lack of happiness in their workplace. Some of them claim their reasons for leaving are as a result of their needs not being met according to their expectations. As a result of this staff turnover, scarce resources of the department get drained. This was also due to the services of these lost staff which is no longer available to be utilized. High staff turnover rates causes a loss to the department in terms of costs incurred to hire and train new employees (Kemal et al. 2002). Too much of a concern is raised within the department and the entire province. It is however imperative to obtain an empirical evidence through an investigation. This may provide information about the nature, the causes and the effects of employee turnover in this organisation. An appropriate conclusion may also be reached through the guidance of the findings from an empirical investigation. Moreover, the paper will establish how this department has recovered from staff turnover situations and what impact this has brought upon them.

\section{Reasons for Staff Turnover}

Many reasons explain why employees withdraw from their work places especially in an economy where skills are relatively scarce and recruitment is costly. This also applies to instances where substantial amount of time is taken to fill vacant positions. Employees voluntarily resign their appointments in organizations for various reasons which can be classified as pull and push factors. The pull factors, according to Sherratt (2000) include the attraction of a new job especially in a growing economy (such as South Africa) with many job opportunities, or resignation by employees from the governmental departments to go into private sectors.

In such cases, it is the availability of alternative jobs that attracts an employee to withdraw from a particular government department. Sherratt (2000) also explains the push factor as a cause of dissatisfaction with the present job and motivates an employee to seek alternative employment elsewhere. Sometimes, it is a mixture of both the pull and push factors. However, some reasons for leaving are entirely explained by domestic circumstances outside the control of any employer. This applies to a typical example where employees relocate with their spouses or partners.

One important push factor that leads to early turnover of new employees is the unrealistic expectations and general lack of knowledge by many job applicants about the nature of the job at the time of employment. Schultz and Schultz (2006) state that unrealistic expectations cause many employees to resign their appointments soon after taking up a new job. Many job applicants have unworkable expectations about their dream jobs but get disillusioned when such expectations are dashed by their employers. Some employers attract applicants with impractical and non-existent conditions of service during interviews. However, when these new employees get on board and the conditions of service promised by the employers are not forthcoming, such employees immediately update their resumes and quit for other jobs (Steers and Porter, 2003).

\section{Costs Associated with Staff Turnover}

Staff turnover impacts heavily on both workers and organizations. It causes disruption and forces employees to learn new job specific skills and find different career prospects (Alogoskoufia et al. 1995). Turnover rates differ from department to department and from sector to sector with a worrying indication that it will continue to rise in the years ahead. Changing demographics affects the labor groups as there are few skilled job candidates from which to hire. Societal norms are also changing, where loyalty to one employer is no longer to be taken for granted. Managers are faced with the increasing need to retain current employees in order to position their departments to be more attractive to talented job applicants Boxall, Macky and Rasmussen (2003).

In their analyses of turnover costs, Schultz and Schultz (2006) and Wagner and Hollenbeck (1995) warned that employee turnover is costly for government departments. Every time an employee quits, a replacement must be recruited, selected, trained, and permitted time on the job to gain experience. Phillips and Connell (2003) concur and enumerate the costs of turnover to include, recruiting costs, selection and or employment costs, orientation costs, training costs, lost wages/salaries, administrative costs, lost productivity, loss of human capital, and customer satisfaction issues. Abassi et al. (2000) emphasize that employees are major contributors to organizations competitive advantage. It is therefore essential for management to discourage staff turnover. According to Testa (2008), organisation should avoid high turnover rates especially one involving skilled professionals as it can pose an inevitable risk due to human capital cost. He argued that these employees by their skilful ability are likely to be re-employed within the same industry by the 
competitor. This may cost the employer according to Johnson et al. (2000) about 50\% of the worker's annual salary to hire and train a replacement worker for a lost employee.

It is important for management to know why employees, particularly high performing employees resign from the departments. The common way of investigating employee's resignation is by conducting an exit interview which also is another cost to the department. The justification given by Phillip and Connell (2003) for such interview is that management is allowed a chance to investigate the persuasive reasons for employee's withdrawal. If the reasons given by the employee suggest inadequacies on the part of the organization, this may serve as a guide to management to review such issues. Moreover, this may help organizations in the formulation of retention policies that adequately provide for the shortcoming.

In conducting an exit interview, some costs are involved and they must be taken into consideration when calculating turnover costs. Bliss (2007) lists these costs to include the time of the person conducting the interview and the administrative costs involved in processing the resignation letter, including stationery and printing. Before a recruitment process is initiated, a job analysis is necessary to determine the job content of the vacant position.

A job analysis expert must be consulted to evaluate outstanding work and job requirements of the vacant position. These costs also represent turnover costs and must as well be accounted for (Greenberg and Baron, 2000). In South Africa, the Employment Equity Act (Act of 1998) and the South African Labour Law provide that a vacant position be publicly advertised before it is filled. Advertisement costs are enormous and constitute a huge loss to organisations especially when many positions are involved. It becomes even more expensive when the services of recruitment agencies are employed as they usually charge between $20-30 \%$ of annual compensation of recruited employee.

This could translate to a huge amount lost when an executive search is concerned. Other recruitment related costs include employee referral, internet posting, and pre-employment tests to help assess candidate's skills, abilities, aptitude, values, and behaviors. Related to these costs as suggested by Bliss (2007) are the selection of applicants, conducting of interviews, preparation of candidates' assessment, employment offer, and notification of successful, and sometimes, unsuccessful candidates too. Having completed employment process, orientation programmes are conducted for new employees in order to familiarize them with the work environment and other employees.

Orientation materials such as products, souvenirs, computers and other materials are prepared and availed during the process. After orientation, new employees are assigned to departments where they are trained for the effective performance of their duties. This involves supervisors and other departmental employees who put in their time in training the new employees. All these attract costs and must be taken into consideration when calculating turnover costs because they represent productivity losses.

Training and retraining of employees constitute one of the most crucial aspects of management in both the public and private sector organizations. According to Choo and Bowley (2007) new employees normally undertake on-the-job training, and in some cases, they are sent abroad to acquire a specialized skill. These costs are enormous and when a highly trained employee resigns without justifying these huge training expenses, departments stand to lose all the investments already accumulated. Long serving employees are normally entitled to gratuity, severance packages, and such benefits as those that will continue to be paid for a lifetime (such as, life pension, medical and child education).

These are unproductive expenses which the DoPW could incur and such expenses may hinder the growth of this department. Meanwhile, many government departments do not have the expertise to determine or calculate the rate of turnover in their selected departments. It is therefore important for managers to keep statistical records of staff retention and turnover for the purpose of human resource planning and formulation of retention policy..

\section{Service termination at DoPW}

Over the past few years, the DoPW has been experiencing high staff turnover rates due to different service termination types. Some of these types of service termination are listed on the first column of Table 1. As an example we selected 2009/10 and 2010/11 financial years only. 
Table 1: Recent statistics of employees who left employment at DoPW

\begin{tabular}{lcc}
\hline Service termination type & April 2009/2010 & April 2010/2011 \\
\hline Deceased & $66(26 \%)$ & $96(28 \%)$ \\
Resigning of position & $21(8.2 \%)$ & $4(1.15 \%)$ \\
Resign (24 hours) & $0(0 \%)$ & $1(0.29 \%)$ \\
Contract expiry & $5(1.96 \%)$ & $2(0.57 \%)$ \\
Service period expired & $1(0.39 \%)$ & $1(0.29 \%)$ \\
III-health - section 17(2) & $6(2.35 \%)$ & $15(4.31 \%)$ \\
Dismissal (discharged) & $7(2.75 \%)$ & $4(1.15 \%)$ \\
Retirement - section 16(1) & $130(51 \%)$ & $154(44 \%)$ \\
Early retirement-section & $2(0.78 \%)$ & $2(0.57 \%)$ \\
Transfers & $17(6.67 \%)$ & $69(19.83 \%)$ \\
\hline Grand total & $\mathbf{2 5 5}$ & $\mathbf{3 4 8}$ \\
\hline
\end{tabular}

Source: www.nwpg.ov.za/Public Works North West Provincial Government

Table 1 gives a summary of recent service termination according to the type from 1 April 2009 to 31 April 2011. It is clear that the majority of employees at the provincial DoPW left their employment due to retirement as scheduled in their retirement policy. However, high and critical turnover rates are surprisingly as a result of death of employees and transfers. III-health and dismissal were also some of the reasons that saw the department loosing employees during these periods.

\section{Study Objectives}

The study is aimed at achieving the following objectives:

- To establish reasons leading to employees' intension to leave the department

- To determine the nature of employees to intend to resign

- To determine the nature and causes of staff turnover

- To formulate suggestions based on the findings to the department on how to manage their department effectively and how to retain employees and reduce turnover

\section{Data and methodology}

\subsection{Data used}

The study is specifically focused on employees in the provincial DoPW. The department has 70 employees in counting as shown in Table 2. All employees including managers at all levels were participants in this study. No sampling technique was used to decide on a sample due to the size of this department.

Table 2: Participants

\begin{tabular}{lcc}
\hline & Frequency & Percent \\
\hline Senior Personnel Officer & 5 & 7.1 \\
Secretary & 4 & 5.7 \\
HOD & 5 & 7.1 \\
Personnel Practitioner Organisational Developer & 5 & 7.1 \\
Senior HR Practitioner & 3 & 4.3 \\
Admin Clerk & 8 & 11.4 \\
Director & 7 & 10.0 \\
Personal Assistant & 5 & 7.1 \\
Security & 4 & 5.7 \\
Office Manager & 4 & 5.7 \\
Admin Officer & 4 & 5.7 \\
Senior Network Controller & 2 & 2.9 \\
Cleaner & 4 & 5.7 \\
Senior Accounting Officer & 3 & 4.3 \\
Intern & 3 & 4.3 \\
General Worker & 2 & 2.9 \\
Supply Chain Management & 2 & 2.9 \\
Total & 70 & 100.0 \\
\hline
\end{tabular}




\subsection{The questionnaire}

A structured questionnaire consisting of three sections was administered to 70 employees and a return rate of $100 \%$ was achieved. Section A of the questionnaire collects data on employee profile. The motive behind Section B was to determine the seek ideas from employees about the causes of staff turnover in the department. The prompt for this section was stated as "please evaluate the extent to which the following motivational variables influence your satisfaction in the department". The scale was assigned as: Strongly Disagree (1), Disagree (2), Agree (3) and Strongly Agree (4). Finally, in Section C, employees were asked to provide their views concerning the resignations in the department and also to confirm their future with this department. Participants were in this section asked to indicate their responses by ticking either "Yes or No".

\subsection{Methods used}

Prior to the processing of results, the data was edited so as to eliminate any incomplete questionnaire. All the questionnaires were found to be valid and complete with no missing information. The study used chi-square analysis to determine the association between turnover and customer satisfaction. A conventional level of $5 \%$ was used in studying the association and arriving to conclusions. The strategy was to reject the test of the association if the observed probability is less than the level of significance $(P<\alpha)$. The results were given as summaries of Chi-square and descriptive statistics.

\section{Results and Discussions}

Presented in this section are the results derived from the process of data analysis.

\subsection{Participants sample statistics}

It is clearly revealed in Table 3 that the majority of employees at the DoPW are largely comprised of females representing $60 \%$ of the sample and $40 \%$ is a representation of males. The majority of these employees are aged between 25 and 40 years and $11.4 \%$ represent those in the elderly age group. Few (4.2\%) of these employees have post matric certificate as their highest qualifications with a reasonable number $(42.9 \%)$ in possession of Bachelor's degrees. Given the varied number of years in service at this department, the proportion of employees with longer service (10 years and more) is less than that of employees with few years of service (less than 10 years).

Table 3: Demographics

\begin{tabular}{lcc}
\hline Vairable & Frequency & Percent \\
\hline \multirow{2}{*}{ Gender } & Male & 40.0 \\
& Female & 60.0 \\
\hline \multirow{3}{*}{ Age group } & $18-25$ years & 7.1 \\
& $25-40$ years & 54.3 \\
& $40-55$ years & 27.1 \\
Highest educational qualification & $55-65$ years & 11.4 \\
& Grade 12 & 10.0 \\
& Post matric certificate & 4.3 \\
& Diploma & 22.9 \\
& Degree & 42.9 \\
Years of service & Other & 20.0 \\
\hline & $0-3$ years & 11.4 \\
& $4-6$ years & 24.3 \\
& $7-9$ years & 27.1 \\
& $10-12$ years & 14.3 \\
\hline
\end{tabular}

Participants were asked to indicate whether or not they have intensions of leaving the department and their responses are shown in Table 4. 
Objective 1: To establish reasons leading to employees' intension to leave the department

Table 4: Do you consider leaving the department?

\begin{tabular}{ccc}
\hline Response & Frequency & Percent \\
\hline Yes & 46 & 65.7 \\
No & 24 & 34.3 \\
\hline Total & 70 & 100.0 \\
\hline
\end{tabular}

A substantial number (65\%) of employees indicated good intentions of leaving their work place according to the responses displayed in Table 4. This may aggravate the already existing problem should this department fail to address staff issues. Trends in staff turnover due to resignation by employees may be escalated. Reasons leading to their resignations are summarised in Table 5.

Employees stated that the major reasons leading to their intentions to resign are in relation to their employer such as lack of governmental culture and benefits that are appealing to them, just as Schultz and Schultz (2006) hinted. Most of them also indicated that their reasons for leaving are not really as a result of lack of skills and education development. This shows a certain level of confidence among staff in this department. The reasons given by employees for envisioned resignations are manageable. This implies that employees decided to leave employment voluntarily which Nel et al. (2008) view as controllable. Owing to the nature of this resignation, the management has a chance to offer better wages, working conditions and opportunities to retain employees according to Price (1997). If intervention is done urgently, the management of this department may be saved from the costs (listed below) associated with staff turnover as suggested by Grobler et al. (2006, cited by Mdindela, 2009).

- Increased recruitment, selection and placement costs

- Increased training and development costs

- Lower productivity, more accidents, scrappage and quality problems

- Disruption in programmes and projects as managers and administrators leave.

Table 5: Reasons for resignation

\begin{tabular}{lcc}
\hline Reasons & Yes & No \\
\hline Governmental culture that is most appealing to employees in the department. & $45.7 \%$ & $54.3 \%$ \\
Benefits that are most important to employees in the department. & $51.4 \%$ & $48.6 \%$ \\
Skills and education development that are most attractive to most employees in this department. & $58.6 \%$ & $41.4 \%$ \\
\hline
\end{tabular}

\section{Objective 2: To establish the nature of employees to intend to resign}

The intention of this objective is to establish the nature of employees intending to resign. The analysis included demographic variables such as gender and duration of service of employees. The results are summarised as chi-square in Table 6.

Table 6: Nature of employees intending to resign

\begin{tabular}{cccc}
\hline Item & $\begin{array}{c}\text { Do you consider leaving this Department? } \\
\text { Chi-Square }(n)\end{array}$ & P-value & Decision \\
\hline Gender & 1.522 & 0.217 & Fail to reject \\
Male & 16 & & \\
Female & 30 & & \\
\hline Duration of service & 4.377 & & \\
0-3 years & 3 & & \\
3-6 years & 11 & & \\
6-9 years & 14 & & \\
9-12 years & 8 & \\
12-15 years & 2 & \\
15-20 years & 8 & & \\
Age distribution & 3.091 & & \\
18-25 years & 2 & & \\
25-40 years & 24 & & \\
40-55 years & 15 & & \\
55-65 years & 5 & & \\
\hline
\end{tabular}

NB: Only responses of people who indicated intension to leave are shown 
The results in Table 6 confirm that the majority of employees who have intentions to resign are females. Few of the newly appointed employees and those who have been with the department for not more than ten years also intend leaving. Though some of the employees have long service with this department, they also confirmed their intension to give up their jobs. Additionally, lots of employees in their mid-lives may be seen voluntarily vacating the department. Chi-square test confirms that there is insignificant association between intention to resign and gender, duration of service and age of employees. This implies that intension to resign is insignificantly influenced by these profiles in the DoPW and confirms that everyone irrespective of gender, service or age may be expected resign in due course.

Objective 3: To determine the causes of staff turnover on employee satisfaction

Presented in Table 7 are chi-square results concerning the causes of staff turnover. The results are significant with respect to:

- No good training and development opportunities

- No challenging and interesting job opportunities

- Lack of participation in decision making process

- Lack of provision of good terminal/retirement benefits

- Lack of conditions of employment that guarantee job security

This is a confirmation that employees are only getting their satisfaction with regards to the five motivational strategies as listed above. The message that employees of this department are trying to put across is more directed to the employer. This suggests a long list of things to plan for both in long term and short term basis. The problem of staff turnover may be unremitting if the management does not intervene sooner. The findings are in accordance with studies by Sailors and Sylvestre (1994), Rampur (2009) and Kwadwo (2012) who reported salaries to be the main cause of turnover. This causes employees to embark on search for jobs that pay well. The authors further contend that employees prefer companies which may provide them with higher posts and increased compensation packages. Sailors and Sylvestre (1994) recommended that organisations should provide the following to employees: fringe benefits, pay competitive or higher salaries, ensure work life balance and subsidize special training or education programs to reduce the employee turnover.

As recommended by Boxall, Macky and Rasmussen (2003), management should make personnel decisions based on merit. This may lessen the proportion of dissatisfaction among employees. The issue of good working relations within the organization needs to be encouraged by management. It is evident that lack of good working relationship amongst employees is another cause of staff turnover posing great challenges to HR practice in the department. Korte (2007) suggested that newly employed staff must be made to feel at home. This could cause them to feel welcome and needed at workplaces. People generally expect to be acknowledged for the job well-done and for their valuable offerings and contribution. Hofmans et al. (2012) highlighted that many employees expect day-to-day informal recognition. This strategy could work well for the department as this is one of the identified determinants of employees' lack of performance in this paper. It is important for management to listen to employees, support and recognize their contributions. This will encourage them to be more engaged in their daily duties (Pavlinac, 2009).

Rampur (2009) also highlighted the following as causes of high staff turnover rates: lack of employee motivation, work pressure, job stress, partiality and favouritism, employee egos and attitudes, poor employee management decisions. These are some of the influential factors to staff turnover in the DoPW as reflected in Table 7.

Table 7: Causes of staff turnover

\begin{tabular}{lccc}
\hline Item & Chi-Square & P-value & Decision \\
\hline Lack of competitive salary package & 54.738 & 0.234 & Fail to reject \\
Lack of opportunity to earn Performance onus/commission/over time & 44.016 & 0.637 & Fail to reject \\
No good training and development opportunities & 79.862 & 0.003 & Reject \\
Lack of recognition and reward for good performance & 46.247 & 0.545 & Fail to reject \\
Lack of promotion based on performance & 53.273 & 0.279 & Fail to reject \\
Lack of opportunity to work independently & 61.858 & 0.086 & Fail to reject \\
Lack of up-to-date technology to perform my job & 58.676 & 0.139 & Fail to reject \\
Lack of mentor who often advices me on my job & 64.961 & 0.052 & Fail to reject \\
No challenging and interesting job opportunities & 93.998 & 0.000 & Reject \\
Lack of participation in decision making process & 82.535 & 0.001 & Reject \\
Lack of encouraging good working relationship amongst employees & 48.788 & 0.441 & Fail to reject
\end{tabular}


Lack of provision of good terminal/retirement benefits

Lack of flexible work arrangement

Setting performance target for all subordinates

Lack of provision of health/wellness programmes for all employees

Lack of conditions of employment that guarantee job security

Lack of strong sense of belonging to this department

Lack of freedom for innovative thinking in executing tasks
$67.451 \quad 0.033$

$44.138 \quad 0.632$

$48.457 \quad 0.454$

$62.870 \quad 0.073$

$58.504 \quad 0.042$

$60.127 \quad 0.113$

58.646
Reject

Fail to reject

Fail to reject

Fail to reject

Reject

Fail to reject Fail to reject

Once more, respondents were asked whether or not they had an experience of staff resignation in their department during the past six months. The responses with regards to this question are summarised in Table 8.

Table 8: Has anyone you know left this department in the past six months?

\begin{tabular}{ccc}
\hline Response & Frequency & Percent \\
\hline Yes & 54 & 77.1 \\
No & 16 & 22.9 \\
\hline Total & 70 & 100.0
\end{tabular}

It is clearly shown in Table 6 that the department have experienced a substantial number of resignations over the past six months. About $77 \%$ of respondents concur that they did witness resignations in their department. Asked if they were made aware about these resignations, about $64 \%$ confirmed their colleagues did confide in them. This may mean that there is a general problem affecting employees in the department and the onus is with the organization to take steps to address those problems as early as possible. This may help retain the department's reputation and discourage employees who have not yet considered leaving the department. The morale of staff could be enhanced and more employees may also be enticed to join the department.

Table 9: Did they discuss reasons that would have made them stay?

\begin{tabular}{ccc}
\hline & Frequency & Percent \\
\hline Yes & 45 & 64.3 \\
No & 25 & 35.7 \\
\hline Total & 70 & 100.0 \\
\hline
\end{tabular}

\section{Conclusions}

The main motivation which prompted the study was a high staff turnover rates among employees of the DoPW of the NWPG and its impact in their performance. A structured questionnaire consisting of three sections was administered to employees of this department. The general picture portrayed by the results of this study is that staff turnover in this department creates employee dissatisfaction. This as indicated causes lots of destructions and leads to more employees having doubts about their future in the workplace. Management factors have been found to be major causes of staff unrest in the department. In the main, employees are dissatisfied about their salaries, recognition and support by management, conducive conditions of employment, etc. They however indicated that they have needed skills and qualifications for their jobs. A substantial number of employees indicated their preparedness to resign should the department fail to address their concerns.

Based on the results and findings discussed, the study makes the following policy recommendations:

Management should give an exceptional attention to controllable factors such as resignation. Other manageable factors such as communication and relationship with staff, fair treatment, recognition for effort, better remuneration packages, performance appraisal, participation in decision making, providing support and encouragement should also be addressed. Though employees indicated that the department does offer training for staff development, it is recommended to management to pay careful attention to line managers as well as new employees. Employees should be provided more opportunities for career advancement and improved qualifications. They should also be placed in appropriate positions according to their skills, abilities, experiences and qualifications. This will prepare them for promotion and enhanced responsibility and may reduce further resignations.

Performance of employees must also be closely monitored and recognised. They must be made aware of the expectations from management as soon as the financial begins. Employees indicated that their job is not challenging explaining that they have been misplaced in their positions. To correct this, the study recommends that management offer challenging job in order to safeguard hope for future prospects to workers. This will also ensure intensified loyalty and 
commitment to the organisation. Loyal and committed employees barely abandon their duties and are always focused on their job. Staff should also be allowed to be innovative thinkers. Their suggestions to the department must be taken in cognisance.

\section{Scope Limitations}

This study has been limited to one provincial department in South Africa due to time constraint, resources and nearness of research areas. The target population was employees at the provincial DoPW. The study scope was only limited to staff turnover nature and causes at this department but there are other issues that may be investigated.

\section{References}

Abassi S.M; \& Hollman K.W. (2000). Turnover: the real bottom line, Public and voluntary turnover in the workplace: a comparison of companies across industries. Thesis prepared for the degree of Master of Science, August, 2007. 1- 49. Available online: http://www.google.com

Alogoskoufia, G.B., C. Bertola, C. Cohen, G. Dolado, D., \& Saint Paul, G. (1995). Unemployment choice Europe (EPR London).

Bliss, W.G. (2007). Cost of employee turnover. Seneca, SC: Bliss \& Associates, Inc. Available at http://www.blissassociates.com /html/articles/cost_of_turnover15.html.

Boxall, P., Macky, K. \& Rasmussen, E. (2003). Labour Turnover and Retention in New Zealand: The Causes and Consequences of Leaving and Staying with Employers Asia Pacific Journal of Human Resources, 41 (2), 196-214.

Choo, S. \& Bowley, C. (2007). Using training and development to affect job satisfaction within franchise, Journal of Small Business and Enterprise Development, 14(2), 339-352.

Doke, L. (2008). Training them young is the way to up the skills base, Sunday/Business Times, 29 June, p. 26. Employment Equity Act (Act of 1998), South Africa.

Greenberg \& Baron, R.A. (2000). Behaviour in organization: understanding and managing the human side of work. (7th ed). Upper Saddle River, NJ, Prentice Hall

Grobler, P.A. \& Warnick S., M.R. Carrel N.F., Elbert, \& Hartfierd, R.D. (2006). Human Resource Management in South Africa. (2nd ed). UK London, Cornwall Institute of Management.

Hofmans, J., De Gieter, S., \& Pepermans, R. (2012). Individual differences in the relationship between satisfaction with job rewards and job satisfaction. Journal of Vocational Behavior. (in press).

Harris, M. 2007. Careless hiring can be disastrous, Sunday/Business Times, November 18. p. 2.

Johnson, J., Griffeth, R.W., \& Griffin M. (2000). Factors discrimination functional and dysfunctional sales force turnover. Journal of Business and Industrial Marketing, 15 (6), 399-415.

Korte, R.F. (April.2007). Learning and socialization in the workplace. Summary of a Colloquium presented to faculty and students of the College of Business and Technology at the University of Texas, Tyler.

Kwadwo, K.E. (2012). Nature and causes of labour turnover among senior and junior staff of Golden Star Resources Wassa Mines. Dissertation submitted to Institute of Distance Learning, Kwame Nkrumah University of Science and Technology.

Lee, G., Magnini, V. P., \& Kim, B. (2011). Employee satisfaction with schedule flexibility: Psychological antecedents and consequences within the workplace. International Journal of Hospitality Management, 30 (1), 22-30.

Mdindela, S.V. (2009). Staff turnover at selected government hospitals. Dissertation submitted in the faculty of Business and Economic Sciences at the Nelson Mandela Metropolitan University, South Africa.

Nel, P.S., Werner, A., Haasbroek, G.D., Poisat, P., Sono, T. \& Schultz, H.B. (2008). Human Resource Management. (8th ed).Oxford University Press, Cape Town.

Pavlinac, J. M. (2009). Reward, Recognition, Remuneration: Consider a Specialty Credential. Journal of the American Dietetic Association, 109(7), 1144.

Phillips, J.J. \& Connell, A.O. (2003). Managing employee retention: a strategic accountability approach. Burlington, Franklin Covey.

Price, J.L. (1997). The study of turnover. Ames, lowa State University.

Rampur, S. (2009). Causes of Employee Turnover. Retrieved November 13, 2009, from Buzzle.com: http://www.buzzle.com/ articles/causes-of-employeeturnover.html

Sailors, J. F. \& Sylvestre, J. (1994). Reduce The Cost Of Employee Turnover. Journal of Compensation and Benefits, 9(5), 32-34.

Schultz, D. \& Schultz, S. E. (2006). Psychology and work today: an introduction to industrial and organizational psychology, New Jersey, Pearson Educational International.

Sherratt, J. (2000). Attracting \& retaining the tight staff. Management today, 16(5), 38 - 39.

Steers, R.M., \& Porter, L.W. (2003). Motivation and work behavior (7th ed.). New York, McGraw Hill Inc.

Testa, B. (2008). Early engagement, long relationships? Workforce Management, 15, 27-31.

Van Der Merwe, R. \& Miller, S. (1993). Measuring absence and labour turnover: A practical guide to recording and control. Johannesburg, Lexicon Publishers.

Wagner, J.A \& Hollenbeck, J.R. (2002). Organizational Behaviour, (4th ed.). New York, McGraw Hill Publishers.

www.nwpg.ov.za/Public Works North West Provincial Government 